\title{
INVESTIGATION OF MEDICAL STUDENTS' EMOTIONAL INTELLIGENCE
}

\author{
VALENTINA KUROVSKA ${ }^{1}$, IHOR OHDANSKYI ${ }^{2}$ \\ ${ }^{1} \mathrm{PhD}$ in Medical Science, assistant of the Department of Physiology, O.O. Bogomolets National \\ Medical University, Kiev (Ukraine) \\ ORCID ID: https://orcid.org/0000-0002-7295-5549 \\ ${ }^{2}$ Private psychologist, Chernivtsy (Ukraine)
}

UDC: $159.942: 61-057.875$

\section{SUMMARY}

The problem of emotional intelligence raises a big interest in the context of training of medical workers, because professional work of doctors is associated with an impact of stressful factors. The ability to keep control over the situation allows to avoid a devastating psychogenic effect on the doctor's personality and indicates their professionalism. The investigation with the aim of assessment of emotional intelligence has been held among medical students of the second year of study of O.O. Bogomolets National Medical University. There were 343 participants in this experiment. We tend to consider the emotional intelligence more as personality traits, not as abilities and because of this our survey was based on Hall's method.

On the base of received data, it was established that 5 students have the high level of emotional intelligence only. That is $1,5 \%$ of the total participants' number. The group with mean EI counted 127 students, which is $37,02 \%$ of the total amount. The group with low EI turned out to be the most numerical: 211 students and $61,51 \%$ of the total amount. The received data suggest that the mean scores in the group with mean level of EI are generally higher than in the group with low level of EI. The level of «emotional awareness» is 1,62 times higher, «management of one's own emotions»-2,93 times, «self-motivation» - 2,02 times, «empathy» - 2,01 times, and «discrimination of other people's emotions» - 2,36 times. Therefore, the biggest difference is observed in the results of «management of one's own emotions» - reducing almost by 3 times in the group with low EI.

Address for correspondence, e-mail: editpsychas@gmail.com Copyright: (C) Valentina Kurovska, Ihor Ohdanskyi

This is an Open Access journal, all articles are distributed under the terms of the Creative Commons AttributionNonCommercial-ShareAlike 4.0 International (CC BY-NC-SA 4.0) License (http://creativecommons.org/licenses/by-nc$\mathrm{sa} / 4.0 /$ ), allowing third parties to copy and redistribute the material in any medium or format and to remix, transform, and build upon the material, provided the original work is properly cited and states its license. 


\begin{abstract}
Because of the prevailing low level of EI among medical students, the necessity of its development has been arisen. It can be achieved by trainings. The concept of creation of trainings should be based on peculiarities of the aim and tasks which they have. In our opinion, the EI trainings should be included in the curriculum in the last years of study. It makes a sense to implement them for medical workers too.

The program of EI training may consist of seven modules with 20 academic hours for each one of them. The modules can be held intermittently. It is planned to devote 6 months to realize the entire program. That is, one module per month can take one day, 10 academic hours, twice per week. The training should be held in the group run by a psychologist (12-15 participants).
\end{abstract}

Keywords: self-efficacy; competence; cognitive behavioral approach; physical health.

\section{Problem definition and its relationship with important scientific and practical tasks}

Nowadays the concept of emotional intelligence (EI) is considered not only as a personal characteristic, which allows one to be successful in one's own activity, but as the necessary part of professionalism in areas where interactions with people is the main component of a job. Emotional intelligence of people may be low, mean or high. Clear awareness that problems, stressful, emotionally negative and difficult situations might happen in life, and the acknowledgement and sensation of one's own abilities to overcome them are features of high emotional intelligence. In this case, emotions from the field of affects transfer to the level of regulatory functions. It allows an individual not to accumulate negative subconscious experience and react instinctively, but to convert negative emotions in a constructive way. Therefore, as soon as the concept about EI was formed, it was suggested to develop and train it.

With the increase of the data about EI, two concepts were formed around it. Some scien- tists considered EI as abilities: the ability to perceive, differentiate and understand one's own and other people's emotions, to control emotions for providing one's own development (Salovey, Backett \& Mayer, 2004). Others, as personal traits: the sum of non-cognitive abilities, competencies and skills, which have a big impact on the ability to cope with challenges and pressure of the environment (Petrides \& Furnham, 2003). The difference between these concepts was based on different approaches and methods of EI study and, in both cases, the data had not correlated with each other (Brannick et al., 2009). In order to eliminate these contradictions, it was suggested considering the concept of EI comprehensively, as a hierarchical structure where the abilities and traits are only different levels of the whole structure (Andreeva, 2009; Knyazev, Mitrofanov \& Bocharov, 2013).

An interesting fact was established on the base of electrophysiological study. The phenomenon of emotional intelligence has neurophysiological base and allows scientists to uncover 
some mechanisms of perception and processing of emotional information. The existence of mechanism which amplifies perception of positive emotions and reduces perception of negative emotions was discovered for people with high level of EI (Knyazev, Mitrofanov \& Bocharov, 2013).

Given the above, the problem of emotional intelligence arouses interest in the sense of training of medical workers. The work of physicians is strongly influenced by stressful factors. Therefore, sensible management of emotions allows physicians to avoid a devastating psychogenic effect on the doctors' personalities and represents their professionalism.

\section{Analysis of recent researches and publications}

In one of the reviews, different ways of training of each EI component were suggested, as well as the problems that prevent trainings from wide introduction into the curriculum were emphasized (Uchino et. al., 2015). First of all, there is a problem of the lack of confidence in the validity of the very idea of EI, because only about 25 years have gone since the moment of introduction of this term and concept. Sources of information popularize the idea of EI, primarily, as a way to succeed in business. Still, it remains as a new issue for medicine. Secondly, the lack of funds and time for implementing trainings in the curriculum play their role. Nevertheless, according to the data of one source, only 8 hours of training are enough for receiving results in the next four years (Dugan, Weatherly, Girod, Barber $\&$ Tsue, 2014). According to another one, trainings which were realized during 18 hours during one weekend, had a visible effect on the next 9 months (Fortney, Luchterhand, Zakletskaia, Zgierska \& Rakel, 2013). In authors' opinion, the lack of well-qualified psychologists is another obstacle on the way of introduction of EI trainings into the curriculum (Uchino et. al., 2015).

Another big review, which also focused attention on the problems of implementation of EI trainings, noticed some main factors which should be taken into account. On the base of analyzed data, it was come to the conclusion that trainings had a greater impact on the improvement of EI among students during the last year of study than the first year. Moreover, it is important to emphasize on the significance of empathy and communication with patients during the whole period of study. As the trainings had generally a more positive impact on women than men, it also should be considered during the development of the very method of training (Cherry, Fletcher, O’Sullivan \& Shaw, 2012).

What is more, such a vital moment as practical application of EI trainings was pointed out in that review. Almost all sources reported that trainings stimulate learning and improve knowledge, but there is almost no data about changes in students' behavior. It is not reported how EI trainings can be applied by medical students in clinic, although it must be their main purpose (Cherry, Fletcher, O'Sullivan \& Shaw, 
2012).

According to the interrelation between EI and IQ or academic achievements, the data are different. It had been found that students with high level of EI of the first and the last year of study were more successful in their academic achievements (Chew, Zain \& Hassan, 2013). However, most researchers pointed out at the absence of the link between EI, IQ, and academic achievements (Nath, Ghosh \& Das, 2015; Shah, Sanisara, Mehta \& Vaghela, 2014; Libbrecht, Lievens, Carette \& Cote, 2014).

\section{Methods and techniques}

Due to the fact that there are two models of EI, different methods of their evaluation exist. If EI is considered as abilities, it is assessed by tests. In this case, EI correlates mostly with general intelligence. If EI is considered as personality traits, it is estimated by questionnaires and correlates mostly with personal characteristics. Respectively, the second method allows better to examine individual distinctions in personal sensation of emotional stimuli (Knyazev, Mitrofanov \& Bocharov, 2013). We have decided to follow the latter concept and in our research adapted Nicolas Hall's method was used (Fetiskin, Kozlov \& Manuilov, 2002). This is a questionnaire, which includes 30 statements of different aspects of perception and reaction to emotional situations, which are scored on a 3-point rating scale ranging from «+» 3 (totally agree) to «-» 3 (completely disagree). The research has been held among students of the second year of study of O. O. Bogomolets National Medical University in Kiev. The number of participants was 343. Students were informed about the aim of the study, confidentiality of results' processing and agreed to take part in the study.

Statistical processing of results has been managed through Microsoft Excel system. Means and standard deviations were calculated, and the data were compared with each other according to a Student's t-criterion.

\section{The main material study with full justification of results}

According to Hall's method, EI of people is divided into three groups: high -70 scores, mean - from 69 to 40 scores and low - from 39 to 0 scores. Among 343 students only 5 showed high EI. That is $1,5 \%$ of the total participants' number and, because of that, the data were not considered during processing of the results. The group with mean EI counted 127 students, which is $37,02 \%$ of the total amount. The group with low EI turned out to be the most numerical: 211 students and $61,51 \%$ of the total amount. These results coincided with the data of most researchers, who also have reported predominance of low scores of EI among medical students (Nazish, Muhammad, Imran \& Anam, 2013; Lolaty, Tirgari \& Fard, 2014; Nath, Ghosh \& Das, 2015). The results of the study are given in the table 1. 


\section{Components of emotional intelligence in the groups with mean and low its level $(M \pm m$; $n=127-$ mean EI, $n=211-$ low EI)}

\begin{tabular}{|l|}
\hline Emotional awareness \\
\hline Management of one's own emotions \\
\hline Self-motivation \\
\hline Empathy \\
\hline Discrimination of other people's emotions \\
$\qquad * \mathrm{p}<0,05$
\end{tabular}

The received data suggest that the mean scores in the group with mean level of EI are generally higher than in the group with low level of EI. The level of «emotional awareness» is 1,62 times higher, «management of one's own emotions» - 2,93 times, «self-motivation» - 2,02 times, «empathy» - 2,01 times, and «discrimination of other people's emotions» 2,36 times. Therefore, the biggest difference is observed in the results of «management of one's own emotions» - reducing almost by 3 times in the group with low EI.

Certain consistency is traced for all five components of EI and it is similar for both groups. Namely, there is a similar tendency in the increase or decrease of the magnitude of each score. «Emotional awareness», «self-motivation», «empathy», «discrimination of other people's emotions» fluctuate almost at the same level, and the score of «management of one's own emotions» is the smallest.

In the group with mean level of EI, «empathy» is the highest, whereas in the group

\section{Mean EI}

$11,44 \pm 0,22 *$

$5,04 \pm 0,20 *$

$10,59 \pm 0,21 *$

$13,08 \pm 0,18$ *

$11,81 \pm 0,19 *$
Low EI

$7,03 \pm 0,15 *$

$1,72 \pm 0,10 *$

$5,23 \pm 0,15 *$

$6,50 \pm 0,16 *$

$5,00 \pm 0,14 *$

with low level of EI «emotional awareness» takes that place.

Some number of students in the group with low EI should be mentioned separately. Their level of emotional intelligence was determined on the base of 2 or 3 EI components only, because in other components they showed 0 score. For example, «emotional awareness» - 7, «self-motivation» - 0 , «empathy» - 5, «discrimination of other people's emotions» - 0, «management of one's own emotions» -0 . These results were observed below 18 as the total score and determined in 28 students, which is $13,27 \%$ in this group and $8,16 \%$ out of all participants. We suppose that these data may indicate disharmonic psychological development of individuals.

In our research it has been found that the low level of emotional intelligence dominates among medical students. This correlates with the data of other scientists. A great number of researchers, who compared the data of EI among medical students of the first and last year of study, have reported that the level of emotional 
intelligence generally is not only low, but remains constant during the educational process (Nath, Ghosh \& Das, 2015; Todres, Tsimtsiou, Stephenson \& Jones, 2010; Chew, Zain \& Hassan, 2015; Khraisat, Rahim \& Yusoff, 2015). It means that tuition in a medical university has no effect on the level of EI. Some data demonstrate that EI even decreased among students of the last year of study. The authors suppose that it could be the result of excessive strictness of educational process (Khraisat, Rahim \& Yusoff, 2015).

Apart from this, it is shown that the data of EI among interns and experienced psychiatrists, independent of their tenue, are not very different. The level of «management of one's own emotions» is the same among interns and experienced doctors. However, the skill of management of other people's emotions is more developed among the latter (Pylyagina, Zubatyuk \& Nosova, 2016).

Because of the prevailing low level of EI among medical students, the unanimous opinion that EI needs to be trained was expressed (Lolaty, Tirgari \& Fard, 2014; Nath, Ghosh \& Das, 2015; Lewis, Rees \& Hudson, 2004; Lolaty, Ghahari, Tirgari \& Fard, 2012; Mathew \& Mathew, 2016). Both the educational process and professional work of doctors are associated with stress, lack of sleep, depression, peculiarities of personal interrelations. If there is no appropriate awareness of how to manage one's own negative emotions sensibly, their consistent suppression during professional communication will only lead to further burnout (Szczygiel, 2018). Therefore, the trainings for students, which would allow them to develop skills of management of their reaction to stress, should be obligatorily included in the curriculum (Doherty, Cronin \& Offiah, 2013). For example, it had been reported that students of the first year of study attended a workshop for EI training in pairs during 2 months. Then they discussed the result in a large group, and $92 \%$ of students were satisfied with that training (Lewis, Rees \& Hudson, 2004).

The concept of creation of trainings should be based on peculiarities of the aim and tasks which they have. Not only does the gender difference play an important role, but also peculiarities of social life. In particular, the data about the level of EI in men and women were controversial. Some authors had reported that the level of EI was higher in men (Khraisat, Rahim \& Yusoff, 2015; Carr, 2009; Ajmal, Javed \& Javed, 2017), others - in women (Nath, Ghosh \& Das, 2015; Malik, Rajkumar, Dharmender \& Sidharth, 2014; Moghal, Yasien, Alvi, \& Washdev, 2016). That contradiction could be explained by the dependence of the results on the nationality, mentality and norms of society (Moghal, Yasien, Alvi \& Washdev, 2016).

In addition, it was suggested that trainings should be focused on the situations which are specific for the doctor's activity. For example, a special questionnaire for medical students was created. Certain situations for clinical daily life with adaptation to Indian conditions were includ- 
ed in the questionnaire. The study also reported low level of EI among students, and authors emphasized on the need in creation of a special scale for estimation of EI, namely among medical workers (Srivastava et.al., 2011).

During the development of trainings, it is also important not to forget that high level of EI cannot be considered as a panacea and does not guarantee the absence of destructive models of behavior. For example, having an ability to control external manifestations of emotions allows to direct aggressiveness in a constructive way (e.g. a healthy competition, a physical activity). However, at the same time, such a property has an opposite effect. Management of other people's emotions may be associated with demonstrative offensiveness, understanding of emotions and management of one's own emotions with vindictiveness. That is, people with high EI tend to use manipulative methods in communication for personal gain (e.g. demonstration of an offense, provoking a conflict) (Andreeva, 2009).

We suggest a general scheme which can be used as the base for creation of EI trainings. In our opinion, the EI trainings should be included in the curriculum in the last years of study, when students spend more time in hospitals. Also, the EI trainings, with psychologists' participation, should be a necessary part of the program of training courses for doctors and nurses. The trainings run by psychologists can be organized in hospitals as special workshops.

For the development of EI we suggest im- plementing a complex approach. First of all, it is necessary to provide basic knowledge about psychology of emotions: typical features, manifestations in facial expression, posture and human behavior. However, the progress in the emotional sphere cannot be limited by theoretical preparation only, the main focus should be laid on the practical part of the development of EI.

This part of study should be based on experience («experiential learning») and interactive methods («training»), which both imply active involvement of learners. The Kolb's model, particularly, belongs to this type of learning ("Kolbs' cycle") (Kolb, 1984). It is a four-step model of experiential learning, and it is based on the sequence and repetition of the following phases: "abstract conceptualization", "active experiment", "individual certain experience" and "reflective observation". In this model there is a consistent movement from a certain idea through experiment and experience and, as a result of which, on the base of observation and reflection, a new concept is built or the existing one is adjusted.

We also believe that the concept of R. Bar-On should be applied during the development of the EI training (Bar-On, 2006). This concept describes a cross-section of interrelated emotional and social competencies, skills and facilitators (factors which facilitate communication). They all have an effect on the intellectual behavior and reflect in self-esteem. This concept expands the notion of EI to the emotional-social in- 
telligence (ECI).

The program of EI training, created on the base of these models, may consist of seven modules with 20 academic hours for each one of them. The modules can be held intermittently. It is planned to devote 6 months to realize the entire program. That is, one module per month can take one day, 10 academic hours, twice per week. This approach is supposed to be the most effective and ensure the achievement of a sustainable result.

Every module should gradually disclose knowledge about recognition of emotions and controlling oneself in different emotional states, and should imply the consideration of every component of EI.

The first module is introduction into the topic, entry diagnostics and acquaintance with the basic concepts. It is important to perform correct diagnostics of each personality and provide every participant with clear awareness of their own positive and negative qualities. The goal of the next five modules (from 2 to 6 ) is a sequential disclosure of the concept of EI, development of skills to distinguish emotions and emotional states, understand how others feel, control emotions, maintain personal efficiency, etc.

The participants should be divided into groups according to their level of EI and according to their 'weak' components of EI. In other words, extra attention needs to be given to the components which have minimum score. For example, in our research the "management of one's own emotions" is the lowest. It means that the training program should contain additional methods for deeper training of this component.

The last module should consist of summing up and final diagnostics (estimation of results and knowledge gained during the process of training).

Since, not only a person's knowledge about EI is important, but also skills and competencies of interpersonal interaction, the training should be in a group (12-15 participants).

\section{Conclusions of the study and prospects for fur- ther research}

1. On the base of our study it has been found that low level of emotional intelligence dominates among students of the second year of study at the medical university. Herewith, the component of «management of one's own emotions» for both groups with mean and low level of EI is characterized by the lowest scores.

2. Taking into account the importance of EI for the professional activity of physicians, either for working with patients or for providing one's own development and prevention of professional burnout, there is the need to train EI, especially for senior students and doctors.

3. The optimal program of the EI training should cover 6 months and consist of 7 modules, each of which should gradually disclose knowledge about emotions, imply the consideration of every component of EI, and train the skills in this area. The trainings are supposed to be in groups. 
The prospect for further research is to create a method of emotional intelligence training for medical students which will be adapt to Ukrainian society conditions, to implement this method and receive the results about its efficiency.

\section{Acknowledgements}

We cordially thank all the students who participated in this research project.

\section{References :}

Ajmal, S., Javed, S. \& Javed, H. (2017). Gender differences in emotional intelligence among medical students. International journal of business and social science, 3(8), 205-207.

Andreeva, I. N. (2009). "Affect" and "intelligence" of the emotional intelligence. Science and education, 6, 8 -12. [Russian]

Bar-On, R. (2006) The Bar-On model of emotional-social intelligence (ESI), Psicothema, 18, 13- 25.

Brannick, M. T., Wahi, M. M., Arce, M., Jonhnson, H. A., Nazian, S. \& Goldin, S. B. (2009). Comparison of trait and ability measures of emotional intelligence in medical students. Medical education, 43, 10621068. doi: 10.1111/j.1365-2923.2009.03430.x

Carr, S. E. (2009). Emotional intelligence in medical students: does it correlate with selection measures? Medical education, 43(11), 1069-1077. https:// doi.org/10.1111/j.1365-2923.2009.03496.x

Cherry, M. G., Fletcher, I., O'Sullivan, H. \& Shaw, N. (2012). What impact do structured educational sessions to increase emotional intelligence have on medical students? Medical teacher, 34, 11-19.
https://doi.org/10.3109/0142159X.2011.614293

Chew, B. H., Zain, A. M. \& Hassan, F. (2013). Emotional intelligence and academic performance in first and final year medical students: a cross-sectional study. BMC medical education, 13, 44-56. https:// doi.org/10.1186/1472-6920-13-44

Chew, B. H., Zain, A. M. \& Hassan, F. (2015). The relationship between the social management of emotional intelligence and academic performance among medical students. Psychology, Health \& Medicine, 2(20), 198-204. doi: $10.1080 / 13548506.2014 .913797$

Doherty, E. M., Cronin, P. A. \& Offiah, G. (2013). Emotional intelligence assessment in a graduate entry medical school curriculum. BMC Medical education, 3, https://doi.org/10.1186/1472-6920-13-38

Dugan, J. W., Weatherly, R. A., Girod, D. A., Barber, C. E. \& Tsue, T. T. (2014). A longitudinal study of emotional intelligence training for otolaryngology residents and faculty. JAMA Otolaryngoljgy Head and Neck Surgery, 140(8), 720-726. doi: 10.1001/ jamaoto.2014.1169.

Fetiskin, N. P., Kozlov, V. V. \& Manuilov, N. P. (2002). Socio-psychological diagnosis of personal development and small groups (study guide). Moscow. Publishing house of the Institute of Psychotherapy, 339. [Russian]

Fortney, L., Luchterhand, C., Zakletskaia, L., Zgierska, A. \& Rakel, D. (2013). Abbreviated mindfulness intervention for job satisfaction, quality of life, and compassion in primary care clinicians: a pilot study. Annals of family medicine, 11(5), 412-420. doi: 10.1370/afm.1511.

Khraisat, A. M., Rahim, Ah. F. \& Yusoff, M. S. (2015). Emotional intelligence of USM medical students. Education in medicine journal, 7(4), 26-38. DOI:10.5959/eimj.v7i4.397 
Knyazev, G. G., Mitrofanov, L. G. \& Bocharov, A. B. (2013). Emotional intelligence and oscillatory responses to emotional facial expressions. Human physiology, 4 (39), 41-48. [Russian]

Kolb, D. (1984) Experiential learning: Experience as the source of learning and development. Englewood Cliffs. New Jersey: Prentice-Hall, 272.

Lewis, N., Rees, Ch. \& Hudson, N. (2004). Helping medical students identify their emotional intelligence. Medical education, 38, 545-576. https:// doi.org/10.1111/j.1365-2929.2004.01872.x

Libbrecht, N., Lievens, F., Carette, B. \& Cote, S. (2014). Emotional intelligence predicts success in medical school. Emotion, 14(1), 64-73. doi: 10.1037/ a0034392.

Lolaty, H. A., Ghahari, S., Tirgari, A. \& Fard, J. H. (2012). The effect of life skills training on emotional intelligence of the medical sciences students in Iran. Indian journal of psychological medicine, 34(4), 350-354. DOI: 10.4103/0253-7176.108217.

Lolaty, H. A., Tirgari, A. \& Fard, J. H. (2014). Emotional intelligence and related factors in medical sciences students of an Iranian university. Iranian journal of nursing and midwifery research, 19(2), 203207. PMC 4020032

Malik, D., Rajkumar., Dharmender, K. N. \& Sidharth, A. (2014). Perceived stress and emotional intelligence in medical students. Indian journal of health and wellbeing, 5(1), 110-114.

Mathew, A. \& Mathew, T. V. (2016). Emotional intelligence of medical students and need for training. International journal of development research, 6 (03), 7168-7171.

Moghal F., Yasien S., Alvi T., \& Washdev. (2016). Relationship of emotional intelligence and stress in undergraduate medical students. Journal of psychology and clinical psychiatry, 5(3): 00282. DOI:

\subsection{6/jpcpy.2016.05.00282}

Nath, S., Ghosh, S. \& Das, Sh. (2015). Relation between intelligence, emotional intelligence, and academic performance among medical interns. Open journal of psychiatry and allied sciences, 6, 96-100. DOI: 10.5958/2394-2061.2015.00004.X

Nazish I., Muhammad A. A., Imran I. H. \& Anam F. (2013). Educating tomorrow's doctors: a cross sectional survey of emotional intelligence and empathy in medical students of Lahore. Pakistan journal of medical sciences, 3(29), 710-714. PMC 3809307

Petrides, K.V., Furnham, A. (2003). Trait emotional intelligence: behavioral validation in two studies of emotion recognition and reactivity to mood

Pylyagina, G. Ya., Zubatyuk, O. V. \& Nosova, Ye. S. (2016). Peculiarities of emotional intelligence in psychiatrists and the possibilities of its development at the stage of postgraduate education. Collection of scientific papers of employees of Shupyk National Medical Academy of postgraduate education, 26, 603-609. [Ukrainian]

Salovey, P., Backett, M. A., \& Mayer, J. D. (2004). Emotional Intelligence: Key Readings on the Mayer and Salovey Model. Port Chester, NY: Dude Publishing, 29-60.

Shah, Ch. J., Sanisara, M., Mehta, H. B. \& Vaghela, H. M. (2014). The relationship between emotional intelligence and academic achievement in medical undergraduate. International journal of research in medical sciences, 2(1), 59-61. DOI: 10.5455/23206012.ijrms20140211

Srivastava, K., Joshi, S., Raichaudhuri, A., Ryali, V., Bhat, P. S., Shashikumar, R., Prakash, J. \& Basannar, D. (2011). Emotional intelligence scale for medical students. Industrial psychiatry journal, 20(1), 39-44. DOI: 10.4103/0972-6748.98413 
Szczygieł, D. (2018). Service with a fake smile and emotional exhaustion. Does emotional intelligence matter? Polish Psychological Bulletin, 49(3), 299310. DOI: $10.24425 / 119497$

Todres, M., Tsimtsiou, Z., Stephenson, A., \& Jones, R. (2010). The emotional intelligence of medical students: an exploratory cross-sectional study. Medical Teacher, 32(1), 42-48. https:// doi.org/10.3109/01421590903199668

Uchino, R., Yanagawa, F., Weigand, B., Orlando, J. P., Tachovsky, T. J. Dave, K. A. \& Stawicki, S. P. (2015). Focus on emotional intelligence in medical education: from problem awareness to systembased solutions. International journal of academic medicine, 1. 9-20.

\section{Куровська Валентина Олегівна}

Кандидат медичних наук, асистент кафедри фізіологіі, Національний медичний університет ім. О.О. Богомольия, м. Київ (Украӥна)

\section{Огданський Ігор Васильович}

Приватний психолог, м. Чернівціі (Украӥна)

\section{ДОСЛІДЖЕННЯ ЕМОЦЙ̆НОГО ІНТЕЛЕКТУ У СТУДЕНТІВ МЕДИКІВ}

Анотація. Проблема емоційного інтелекту викликає інтерес у сенсі підготовки медичних працівників, оскільки повсякденна робота медика постійно пов'язана 3 впливом стресових чинників. Вміння зберігати контроль над ситуацією дозволяє уникнути руйнівного психогенного впливу на особистість лікаря та є показником його професіоналізму. 3 метою оцінки рівня емоційного інтелекту було проведено дослідження серед студентів- медиків другого курсу навчання Національного медичного університету ім. О.О. Богомольця. У дослідженні взяли участь 343 студенти. Ми схильні розглядати емоційний інтелект як риси особистості, а не як здібності, тому за основу дослідження була взята методика Н. Холла.

На основі отриманих даних встановлено, що лише у 5-ти студентів рівень емоційного інтелекту виявився високим. Це складає 1,45 \% від загальної кількості опитаних. Група 3 середнім рівнем емоційного інтелекту складає 37, 02 \%. Група 3 низькими показниками $€$ найбільш численною: 221 студенти, що складає $61,51 \%$ від загальної кількості учасників. Отримані дані по середнім показникам досліджуваних компонентів емоційного інтелекту в групі з середнім EI, у цілому, вищі, в порівнянні 3 групою 3 низьким ЕI. Так, рівень «емоційної обізнаності» вище у 1,62 рази, «управління емоціями» - в 2,93 рази, «самомотивація» - в 2,02 рази, «емпатія» - в 2,01 рази, «розпізнавання емоцій інших» - в 2,93 рази. Найбільша різниця встановлена за показником «управління емоціями» - зменшення майже в 3 рази в групі з низьким EI.

В зв'язку з переважанням низького рівня емоційного інтелекту серед студентів медиків виникає необхідність у його розвитку. Цього можна досягнути шляхом тренінгів. До питання розробки даних тренінгів необхідно підходити 3 врахуванням мети та задач, які вони мають. На нашу думку доцільно включи- 
ти тренінги по розвитку емоційного інтелекту в навчальну програму на останніх курсах навчання. Також має сенс проводити їх для працівників медичних закладів.

Програма тренінгів може складатися 3 7 модулів по 20 академічних годин кожен. Модулі можуть проводитись 3 перервами. На всю програму передбачається час впродовж 6 місяців. Наприклад, 1 модуль в місяць (1 день 10 академічних годин, один раз на два тижні). Навчання повинно проводитись в групі під керівництвом психолога (12-15 учасників).

Ключові слова: емоційний інтелект, студенти-медики, тренінг емоційного інтелекту.

\section{Куровская Валентина Олеговна}

Кандидат медицинских наук, ассистент кафедры физиологии, Национальный медицинский университет им. А.А. Богомольиза, г. Киев (Украина)

\section{Огданский Игорь Васильевич}

Частный психолог, г. Черновиы (Украина)

\section{ИССЛЕДОВАНИЕ ЭМОЦИОНАЛЬНОГО ИНТЕЛЛЕКТА У СТУДЕНТОВ МЕДИКОВ}

Аннотация. Проблема эмоционального интеллекта (ЭИ) вызывает интерес в контексте подготовки медицинских работников, поскольку каждодневная работа медика постоянно связана с влиянием стрессовых факторов. Умение держать контроль над ситуацией позволяет избежать разрушительного психогенного влияния на личность медика и является показателем его профессионализма. С целью оценки уровня эмоционального интеллекта было проведено исследование среди студентов медиков второго курса Национального медицинского университета им. А. А. Богомольца. В исследовании приняли участие 343 студента. Мы склонны рассматривать эмоциональный интеллект более как черты личности, а не как способности, поэтому за основу исследования была взята методика Н. Холла.

На основании полученных данных установлено, что только у 5-ти студентов уровень эмоционального интеллекта высокий. Это составляет 1,45 \% от общего количества. Группа со средним уровнем эмоционального интеллекта составляет $37,02 \%$. Группа с низкими показателями является наиболее численной: 221 студент, что составляет 61, 51\% от общего числа опрошенных. Полученные данные по средним показателям исследуемых компонентов эмоционального интеллекта в группе со средним ЭИ в целом выше, в сравнении в группой с низким ЭИ. Так, уровень «эмоциональной осведомлённости» выше в 1,62 раза, «управление эмоциями» - в 2,93 раза, «самомотивация» - в 2,02 раза, «эмпатия»- в 2, 01 раза и «распознавание эмоций других»- в 2,93 раза. Наибольшая разница установлена за показателем «управление эмоциями» - уменьшение почти в 3 раза в группе с низким ЭИ.

В связи с преобладанием низкого уровня эмоционального интеллекта среди студен- 
тов медиков возникает необходимость в его развитии. Этого можно достичь путём тренингов. К вопросу разработки подобных тренингов необходимо подходить с учётом особенностей цели и задач, которые они имеют. По нашему мнению целесообразно включить тренинги по развитию эмоционального интеллекта в учебную программу на последних курсах обучения. Также, имеет смысл проводить их для работников медицинских учреждений.

Программа тренингов эмоционального интеллекта может состоять из семи модулей по 20 академических часов каждый. Модули могут проводится с перерывами. На всю программу предусматривается время продолжительностью 6 месяцев. Например, 1 модуль в месяц (1 день 10 академических часов, один раз на две недели). Обучение должно проводится в группе под руководством психолога (12-15 участников).

Ключевые слова: эмоциональный интеллект, студенты-медики, тренинг эмоционального интеллекта. 